\title{
Correction to: High burden of undernutrition among primary school-aged children and its determinant factors in Ethiopia; a systematic review and meta- analysis
}

Moges Agazhe Assemie ${ }^{1 *}$, Alehegn Aderaw Alamneh², Daniel Bekele Ketema' ${ }^{1}$, Ali Mekonen Adem³, Melaku Desta ${ }^{4}$, Pammla Petrucka ${ }^{5,6}$ and Mekdes Marew Ambaw ${ }^{7}$

Correction to: Ital J Pediatr 46, 118 (2020) https://doi.org/10.1186/s13052-020-00881-w

After publication of this article [1], it is noticed one of the author names is incorrect:

'Melaku Desita' should be corrected to 'Melaku Desta'. The author name has been thus updated in this Correction.

The original article has also been updated.

\section{Author details}

${ }^{1}$ Biostatstics Unit, Department of Public Health, College of Health Science, Debre Markos University, P.O. Box: 269, Debre Markos, Ethiopia. ${ }^{2}$ Department of Human Nutrition and Food Sciences, College of Health Sciences, Debre Markos University, Debre Markos, Ethiopia. ${ }^{3}$ Biostatstics Unit, College of Health Science, Assossa University, Assossa, Ethiopia. ${ }^{4}$ Department of Midwifery, College of Health Sciences, Debre Markos University, Debre Markos, Ethiopia. ${ }^{5}$ College of Nursing, University of Saskatchewan, Saskatoon, Canada. ${ }^{6}$ School of Life Sciences and Bioengineering, Nelson Mandela African Institute of Science and Technology, Arusha, Tanzania. 'Department of Agricultural Economics, College of Agriculture and Resource Management, Dilla University, Dilla, Ethiopia.
Published online: 09 September 2020

\section{Reference}

1. Assemie MA, Alamneh AA, Ketema DB, et al. High burden of undernutrition among primary school-aged children and its determinant factors in Ethiopia; a systematic review and meta-analysis. Ital J Pediatr. 2020;46:118. https://doi.org/10.1186/s13052-020-00881-w.

The original article can be found online at https://doi.org/10.1186/s13052020-00881-W.

* Correspondence: agazhemoges@gmail.com

'Biostatstics Unit, Department of Public Health, College of Health Science, Debre Markos University, P.O. Box: 269, Debre Markos, Ethiopia

Full list of author information is available at the end of the article

(c) The Author(s). 2020 Open Access This article is licensed under a Creative Commons Attribution 4.0 International License, which permits use, sharing, adaptation, distribution and reproduction in any medium or format, as long as you give appropriate credit to the original author(s) and the source, provide a link to the Creative Commons licence, and indicate if changes were made. The images or other third party material in this article are included in the article's Creative Commons licence, unless indicated otherwise in a credit line to the material. If material is not included in the article's Creative Commons licence and your intended use is not permitted by statutory regulation or exceeds the permitted use, you will need to obtain permission directly from the copyright holder. To view a copy of this licence, visit http://creativecommons.org/licenses/by/4.0/ The Creative Commons Public Domain Dedication waiver (http://creativecommons.org/publicdomain/zero/1.0/) applies to the data made available in this article, unless otherwise stated in a credit line to the data. 